\title{
Lack of Additional Benefit of Intracoronary Transplantation of Autologous Peripheral Blood Stem Cell in Patients With Acute Myocardial Infarction
}

\author{
Jin-Ho Choi***; Jinoh Choi*; Wang-Soo Lee*; Il Rhee*; Sang-Chol Lee*; \\ Hyeon-Cheol Gwon*; Sang Hoon Lee*; Yeon Hyeon Choe"; \\ Dae Won Kim ${ }^{\dagger}$; Wonhee Suh\$; Duk-Kyung Kim\$; Eun-Seok Jeon*
}

\begin{abstract}
Background Recently the potential of myocardial repair by transplantation of autologous bone marrow stem cells has been suggested. Whether the additional intracoronary transplantation of autologous peripheral blood stem cells (PBSC), which were mobilized by granulocyte-colony-stimulating factor (G-CSF), could safely improve myocardial function in patients with acute myocardial infarction (AMI) was investigated.

Methods and Results Seventy-three patients with AMI who had successfully undergone percutaneous coronary intervention (PCI) were enrolled in the present prospective nonrandomized open-labeled study. Ten patients with elective PCI received G-CSF for 4 days followed by intracoronary PBSC transplantation. Thirty-two patients with primary PCI and 31 patients with recent AMI and elective PCI served as controls. The left ventricular (LV) function was evaluated using echocardiography and magnetic resonance imaging. G-CSF and intracoronary transplantation of PBSC did not incur any periprocedural myocardial damage. After 6 months, the LV ejection fraction was significantly improved in the cell therapy group. For 2 years of the follow-up period, there was no adverse clinical events, except one asymptomatic in-stent restenosis. However, comparable improvement of the LV ejection fraction was also identified in the primary PCI and elective PCI control groups.

Conclusions In the present study, additional intracoronary infusion of PBSC was safe and feasible for the patients with AMI who had undergone PCI, but did not lead to a significant improvement in LV function compared to standard reperfusion treatment. (Circ J 2007; 71: 486-494)
\end{abstract}

Key Words: G-CSF; Left ventricular function; Myocardial infarction; Stem cell

I $\mathrm{n}$ the treatment of acute myocardial infarction (AMI), loss of myocardium and subsequent heart failure remain a major challenge despite major advances in the rapid reperfusion technologies! On the basis of recent experimental studies that suggested the profound benefit of stem cell therapy for myocardial regeneration or healing, several clinical trials have explored the hypothesis that intracoronary infusion of autologous bone marrow stem cells may enhance the recovery of left ventricular (LV) function after $\mathrm{AMI}^{2,3}$ However, the results are still not conclusive and also the risk of adverse cardiac events has been addressed4-11

To assess the safety and effectiveness of autologous adult stem cell transplantation in patients with AMI, we conducted an open-labeled phase II prospective clinical trial.

(Received September 26, 2006; revised manuscript received January 5, 2007; accepted January 17, 2007)

**Department of Emergency Medicine, *Department of Medicine, ${ }^{\$}$ Department of Radiology, Department of Laboratory Medicine and "Samsung Biomedical Research Institute, Samsung Medical Center, Sungkyunkwan University School of Medicine, Seoul, Korea

Conflict of interest: No conflict exists. This work was supported by the Samsung Biomedical Research Institute (SBRI) grant, \#SBRI CA4-118-1, and the intramural fund of the Cardiac and Vascular Center, Samsung Medical Center, 2003, to Dr Eun-Seok Jeon.

Mailing address: Eun-Seok Jeon, MD, PhD, Department of Medicine, Sungkyunkwan University School of Medicine, Cardiac and Vascular Center, Samsung Medical Center, Samsung Biomedical Research Institute, 50 Irwon-dong, Gangnam-ku, Seoul, 135-710, Korea. E-mail: esjeon@smc.samsung.co.kr
Granulocyte colony stimulating factor was used for the mobilization of peripheral blood stem cells, because granulocyte-colony-stimulating factor (G-CSF) is a well-known peripheral blood stem cells (PBSC) mobilizer and the mobilization of PBSC is less invasive than direct bone marrow aspiration followed by cell processing! ${ }^{2}$

\section{Methods}

\section{Patients}

Between August 2003 and April 2004, we enrolled a series of 73 patients within 14 days of anterior ST-segment elevation AMI, who had received successful reperfusion treatment by percutaneous coronary intervention (PCI). We enrolled only patients with the proximal left anterior descending coronary artery (LAD) or mid LAD above first diagonal branch as the culprit vessel due to the following reasons. First, the location of the infarct on the site of vessel occlusion is known to affect the improvement of LV dysfunction, ${ }^{13-16}$ and clinical studies have shown that the LV ejection fraction is lower in anterior myocardial infarction (MI) than the inferior or lateral MI of the same infarct size ${ }^{17,18}$ Second, the infarct location was similar to the experimental models in which the profound effect of cell therapy was shown',3,19 To avoid the dilution of any treatment effect, we excluded patients who presented within $2 \mathrm{~h}$ of symptom onset or patients with other small infarctions. Patients with persistent severe LV dysfunction (LV ejection fraction less than $25 \%$ ), uncontrolled myocardial ischemia 


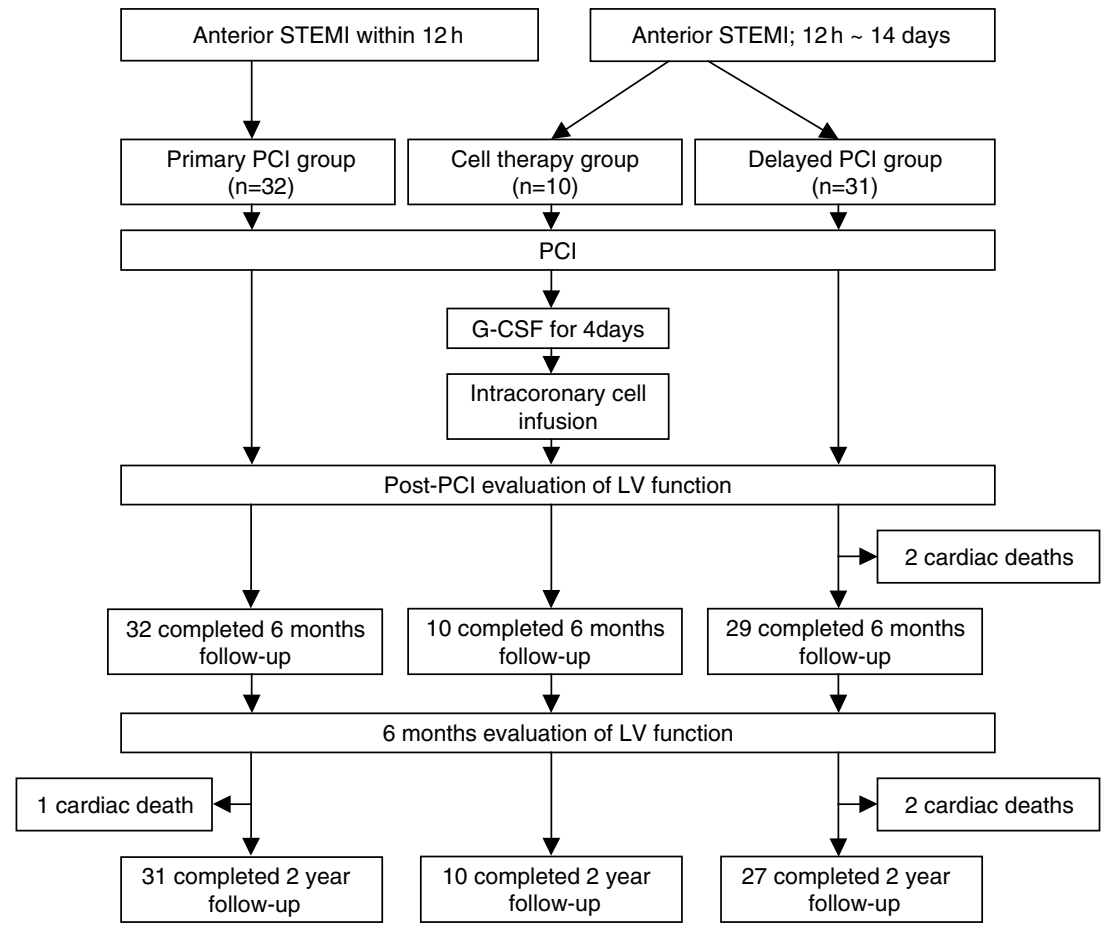

Fig 1. The study profile. PCI, percutaneous coronary intervention; G-CSF, granulocytecolony-stimulating factor; LV, left ventricular. or ventricular arrhythmia, serious current infection or hematological disease and a life expectancy of less than 1 year were also excluded. We compared the results of cell therapy simultaneously with the primary PCI group, which is the current recommended treatment strategy and is proved to improve LV function, with the elective PCI group that had the same AMI-to-PCI time interval to the cell therapy group ${ }^{20-22}$ The institutional review board of the Samsung Medical Center approved the study protocol and written informed consent for each treatment was obtained from all participants.

\section{Study Design}

The overall trial profile is shown in Fig 1. Patients who had undergone PCI within $12 \mathrm{~h}$ of the onset of symptoms comprised the primary PCI group $(n=32)$. Cell therapy was planned for patients who undergone PCI beyond $12 \mathrm{~h}$ of the onset of symptoms. After considering the experimental nature of cell therapy and the recommendations from institutional review board, patients who agreed to cell therapy were enrolled into the cell therapy group $(n=10)$, and patients who refused additional cell therapy served as the delayed PCI group $(n=31)$.

\section{Procedures}

In cell therapy group, PBSC were mobilized by daily subcutaneous injections of G-CSF $600 \mu \mathrm{g}\left(8.6 \pm 1.3 \mu \mathrm{g} \cdot \mathrm{kg}^{-1}\right.$. day ${ }^{-1}$, Dong-A pharmaceutical, Seoul, Korea) for 4 days. PBSC was obtained using COBE spectra apheresis system (COBE BCT Inc, Lakewood, CO, USA) at day 4 (5.9 \pm 2.7 days after PCI), and followed by transradial cardiac catheterization immediately after apheresis. A total of $10 \mathrm{ml}$ PBSC containing $2.03 \pm 0.69 \times 10^{9}\left(1.13-3.25 \times 10^{9}\right)$ mononuclear cells, which contains $3.12 \pm 2.19 \times 10^{6}\left(0.9-8.3 \times 10^{6}\right)$ CD34+ cells, was infused into the infarct-related coronary artery through a microinfusion catheter (Excelsior, Boston Scientific, MA, USA) using a 3-4 fractional manual infusion. To allow adherence and to maximize the potential transmigra- tion of the infused cells through coronary vascular endothelium, intravascular flow was stopped for $60 \mathrm{~s}$ at the end of each infusion using a low-pressure inflation of intracoronary balloon occlusion system (Guardwire, Medtronic, MI, USA).

\section{Characterization of Infused Cells}

The PBSC apheresis product, which consisted of a heterogeneous cell population, was characterized by fluorescence-activated cell sorter analysis (FACSCalibur, Becton Dickinson, CA, USA) using directly conjugated antibodies against anti-human CD34, anti-CD14, antiKDR, anti-VE cadherin and anti-vWF (BD Biosciences). PBSC included $0.15 \pm 0.07 \%$ of CD34+ cells, $0.74 \pm 0.39 \%$ of KDR+ cells, $0.09 \pm 0.09 \%$ of VE cadherin+ cells and $1.52 \pm 0.93 \%$ of $\mathrm{vWF}+$ cells 3,23

\section{Assessment of LV Function}

Two-dimensional echocardiography was performed 4 days (range 3-5) after PCI and at 6 months' follow-up for all participants (Sequoia C512, Acuson, Siemens Medical Systems, PA, USA). LV ejection fraction was calculated using the biplane modified Simpson's method. The wall motion score index was calculated from the average sum of wall motion scores. Cardiac magnetic resonance imaging (MRI, 1.5-T system; GE Signa CVi, General Electric Medical Systems, Milwaukee, WI, USA) was performed in the cell therapy group and the primary PCI group at day 4 (range 3-5) and after 6 months. All images were acquired using a cardiac phase-array coil during breath-holds and were electrocardiographically-triggered. Cine images of the entire left ventricle were acquired in contiguous short-axis views using Fast Imaging Employing Steady-state Acquisition method with a field-of-view (FOV) of $250 \mathrm{~mm}$ and $6 \mathrm{~mm}$ slice thickness. The LV ejection fraction and regional wall motion was analyzed using the MASS 4.0.1 software (Medical Imaging Systems, Leiden, The Netherlands). First-pass perfusion imaging was obtained after intravenous infusion of gadolinium-diethylenetriaminepentaac- 
Table 1 Demographic, Clinical, and Procedural Characteristics of the Study Population

\begin{tabular}{|c|c|c|c|}
\hline & $\begin{array}{l}\text { Cell therapy } \\
(n=10)\end{array}$ & $\begin{array}{c}\text { Primary } P C I \\
(n=32)\end{array}$ & $\begin{array}{c}\text { Delayed PCI } \\
\quad(n=31)\end{array}$ \\
\hline Age & $50.5 \pm 10.6^{*}$ & $55.1 \pm 11.2$ & $64.4 \pm 9.2$ \\
\hline Men, $n(\%)$ & $10(100)$ & $29(91)$ & $24(77)$ \\
\hline Diabetes, $n(\%)$ & $4(40)$ & $9(28)$ & $12(39)$ \\
\hline Hypertension, $n(\%)$ & $3(30)$ & $15(47)$ & $15(48)$ \\
\hline Hyperlipidemia, $n(\%)$ & $2(20)$ & $5(16)$ & $4(13)$ \\
\hline Smoking, $n(\%)$ & $5(50)$ & $17(53)$ & $10(32)$ \\
\hline Previous revascularization, $n(\%)$ & $0(0)$ & $1(3)$ & $2(6)$ \\
\hline Previous stroke, $n(\%)$ & $0(0)$ & $1(3)$ & $1(3)$ \\
\hline Time to revascularization, mean/median, days & $8.3 \pm 8.2 / 7$ & $0.3 \pm 0.3 / 0$ & $8.4 \pm 7.1 / 5$ \\
\hline Maximal $C K-M B, U / L$ & $174 \pm 266$ & $241 \pm 106$ & $45 \pm 60 *$ \\
\hline \multicolumn{4}{|l|}{ Medications on discharge } \\
\hline Aspirin and clopidogrel, \% & 100 & 100 & 100 \\
\hline$\beta$-blocker, \% & 100 & 97 & 97 \\
\hline ACE inhibitor, \% & 100 & 100 & 100 \\
\hline Statin, \% & 100 & 100 & 100 \\
\hline \multicolumn{4}{|l|}{ Culprit vessel } \\
\hline Proximal LAD, $n(\%)$ & $7(70)$ & $22(69)$ & $15(48)$ \\
\hline Mid LAD, $n(\%)$ & $3(30)$ & $10(31)$ & $16(52)$ \\
\hline \multicolumn{4}{|l|}{ Primary Device } \\
\hline Drug-eluting stent, $n(\%)$ & $6(60)$ & $8(25)$ & $11(36)$ \\
\hline Bare metal stent, $n(\%)$ & $3(30)$ & $23(72)$ & $19(61)$ \\
\hline Balloon only, $n(\%)$ & $1(10)$ & $1(3)$ & $1(3)$ \\
\hline Device diameter $(\mathrm{mm})$ & $3.50 \pm 0.33 *$ & $3.27 \pm 0.38$ & $3.11 \pm 0.38 *$ \\
\hline Device length $(\mathrm{mm})$ & $20.70 \pm 4.79$ & $21.81 \pm 6.15$ & $22.13 \pm 7.54$ \\
\hline TIMI grade (baseline) & $1.3 \pm 1.3$ & $0.53 \pm 1.0$ & $2.3 \pm 1.1 *$ \\
\hline TIMI grade (after PCI) & $3.0 \pm 0.0$ & $3.0 \pm 0.0$ & $3.0 \pm 0.0$ \\
\hline
\end{tabular}

$P C I$, percutaneous coronary intervention; $C K-M B$, creatine kinase myocardial band; ACE, angiotensin-converting enzyme; LAD, left anterior descending artery; TIMI, Thrombolysis in Myocardial Infarction.

The device diameter and device length denote the size of stent used.

Data are mean $\pm S D$ when appropriate.

etate (Magnevist, Schering, Berlin, Germany; $0.15 \mathrm{mmol} / \mathrm{kg}$ body weight in total amount at $3 \mathrm{ml} / \mathrm{s}$ ). The slice thickness was $6 \mathrm{~mm}$ with a FOV of $40 \times 40 \mathrm{~cm}$ and image matrix of $128 \times 128$ and images of 6 or 7 locations. Every 2 heartbeats were obtained for 40 phases using a fast gradient echo train sequence (repetition time (TR)/echo time (TE) $=7.3 \mathrm{~ms} / 1.8 \mathrm{~ms}$ ). Late enhancement imaging was performed using an inversion-recovery pulse prepared fast gradient echo recalled technique $(\mathrm{TR} / \mathrm{TE} /$ inversion time $=5.5 \mathrm{~ms} / 1.4 \mathrm{~ms} / 200 \mathrm{~ms}$; slice thickness, $6 \mathrm{~mm}$ with $10 \mathrm{~mm}$ interslice gap; FOV, $40 \times 40 \mathrm{~cm}$; image matrix, $256 \times 160$ ).

\section{Evaluation of Coronary Artery Restenosis and Coronary Hemodynamics}

Follow-up angiography was performed at 6 months after enrollment in all cell therapy group patients, $75 \%$ of the primary PCI group $(n=24)$ and $55 \%$ of the delayed PCI group $(n=17)$. In these patients, quantitative coronary angiography (QCA) was done as the baseline, immediately after PCI and at 6 months' follow-up with Philips QCA software (Pie medical imaging, Maastricht, Netherlands). Identical unforeshortened coronary projections were used and analyzed. Binary restenosis was defined as more than $50 \%$ loss of luminal diameter within the stent $\pm 5 \mathrm{~mm}$.

In cell therapy group, we evaluated the effect of cell infusion on myocardial microcirculation through measurement of the coronary flow reserve of the infarct-related artery, immediately before and after cell infusion and at 6 months' follow-up. A coronary Doppler wire was positioned just distal to the implanted stent in the culprit lesion and an intracoronary bolus injection of $18 \mu \mathrm{g}$ adenosine was used to induce hyperemia4
Parameters of Safety and Feasibility

All patients underwent regular follow-up visits for assessment of their clinical status, any adverse reactions and their medication at 1 month and every 3 months thereafter. Patients were treated with aspirin, clopidogrel, $\beta$ blockers, angiotensin-converting enzyme (ACE) inhibitor and statin, unless these agents were contraindicated. Clinical, treatment and safety laboratory data were prospectively colleted by research nurses. The safety of the cell therapy was assessed on the basis of the development of major adverse cardiac events and their clinical status, including G-CSF related pain, biochemical tests and arrhythmia.

\section{Statistical Analysis}

Continuous variables are presented as the mean $\pm \mathrm{SD}$ or median. Categorical variables are compared using the chisquare test or Fisher's exact test. Statistical comparisons between the initial and follow-up data were performed in a nonparametric manner using the Wilcoxon signed rank test. One-way ANOVA was performed to evaluate differences between groups. A trend in survival scores across the groups was calculated using a log-rank test for trends. All tests were two-tailed and p-values of less than 0.05 were considered to be statistically significant. We used SPSS (version 11.5, SPSS Inc) for statistical analyses.

\section{Results}

\section{Study Population}

The demographic and clinical characteristics of the study population are summarized in Table 1. Aspirin, clopidogrel, $\beta$-blockers, ACE inhibitors and statin were initiated and continued in all patients during study period, except 2 
Table 2 Echocardiographic Evaluation of LV Function

\begin{tabular}{lccc}
\hline \hline & Cell therapy & Primary PCI & Delayed PCI \\
\hline LVEF $(\%)$ & & & \\
Basal & $40.1 \pm 6.5$ & $42.6 \pm 6.3$ & $42.1 \pm 8.0$ \\
6 month & $49.4 \pm 13.4$ & $48.6 \pm 7.1$ & $48.5 \pm 12.3$ \\
Change & $9.3 \pm 12.5$ & $6.0 \pm 7.7$ & $6.5 \pm 8.9$ \\
p value & $0.047^{*}$ & $0.001^{*}$ & $0.002^{*}$ \\
WMSI & & & \\
Basal & $1.87 \pm 0.37$ & $1.82 \pm 0.24$ & $1.80 \pm 0.36$ \\
6 month & $1.60 \pm 0.46$ & $1.56 \pm 0.34$ & $1.61 \pm 0.45$ \\
Change & $-0.27 \pm 0.37$ & $-0.26 \pm 0.39$ & $-0.21 \pm 0.38$ \\
p value & $0.038^{*}$ & $0.001^{*}$ & $0.001^{*}$ \\
\hline
\end{tabular}

LV, left ventricular; LVEF, LV ejection fraction; WMSI, wall motion score index. Other abbrevistion see in Table 1. Data are mean $\pm S D$.

${ }^{*} p<0.05$ between initial and 6-months follow up (Wilcoxon Signed Ranks test).

\section{Cell therapy}

A

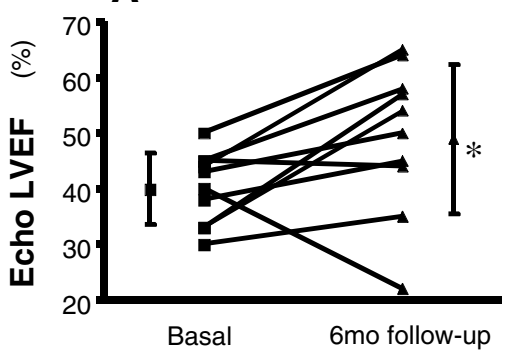

Cell therapy

D

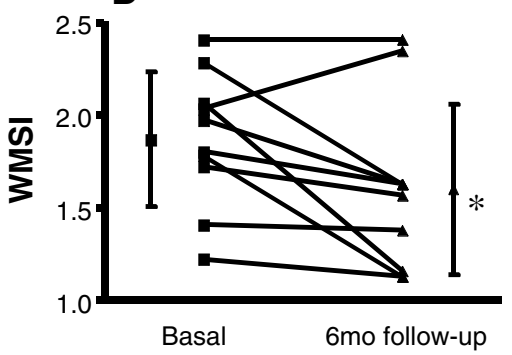

Primary PCI

\section{B}

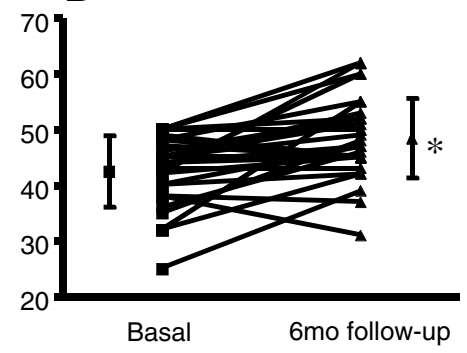

Primary PCI

\section{E}

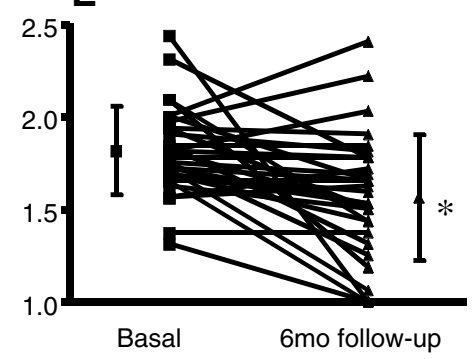

Delayed PCI

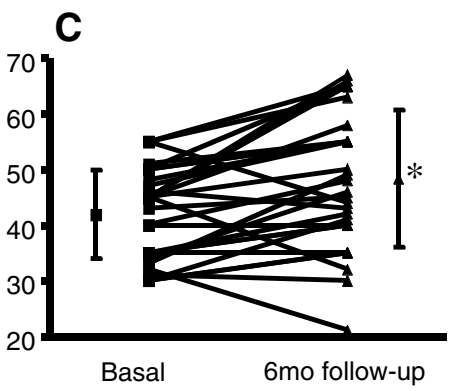

Delayed PCI

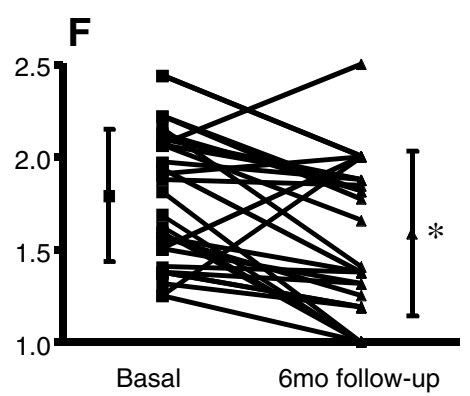

Fig 2. Improvement of left ventricular (LV) function evaluated by echocardiography. LV ejection fraction (LVEF), measured initially and at 6-months $(6 \mathrm{mo})$ follow-up, increased significantly in all groups $(\mathrm{A}-\mathrm{C})$. LV wall motion analyzed by wall motion score index was also improved significantly in all groups (D-F). ${ }^{*} \mathrm{p}<0.05$ between initial and 6-months follow-up (Wilcoxon Signed Ranks test). PCI, percutaneous coronary intervention; WMSI, wall motion score index.

patients who stopped taking $\beta$-blockers due to symptomatic sinus bradycardia. The cell therapy group was younger compared to the other groups. The time to revascularization was shorter in the primary PCI group. Maximal creatine kinase (CK)-MB was significantly lower in the delayed PCI group. Baseline Thrombolysis in Myocardial Infarction grade was significantly higher in the delayed PCI group.

\section{Safety Issues}

The peripheral white blood cell count reached up to $3.51 \pm 0.90 \times 10^{4} \mathrm{~mm}^{-3}$ after G-CSF treatment in cell therapy group, which was significantly higher than in the primary PCI group $\left(1.23 \pm 0.34 \times 10^{4}\right)$ or delayed PCI group $(0.96 \pm$ $\left.0.39 \times 10^{4}\right)(\mathrm{p}=0.001)$. Intracoronary cell infusion did not induce a significant elevation of CK-MB $(2.3 \pm 3.2 \mathrm{ng} / \mathrm{ml}$ after $24 \mathrm{~h})$, which is less than the cut-off value $(5 \mathrm{ng} / \mathrm{ml})$. Furthermore, cell infusion did not affect coronary microcir- culation, which was assessed using the coronary flow reserve (before vs after infusion, $1.90 \pm 0.5$ vs $1.82 \pm 0.49$, $\mathrm{p}=\mathrm{NS}$ ).

G-CSF treatment was well tolerated in all patients. There were no symptoms or signs of myocardial ischemia or arrhythmia in the periprocedural period. There was also no other serious adverse actions or clinical events such as GCSF-related pain. In-hospital telemetric monitoring and $24 \mathrm{~h}$ Holter monitoring at 6 months revealed no ventricular arrhythmia in the cell therapy group.

\section{Improvement of LV Function}

At 6 months after PCI, the global LV function evaluated using echocardiography improved significantly in all groups. The relative improvement in the LV ejection fraction was $9.3 \pm 12.5 \%$ for cell therapy group, $6.0 \pm 7.7 \%$ for primary PCI group and $6.5 \pm 8.9 \%$ for delayed PCI group. The regional wall motion evaluated using the wall motion 
Table 3 Evaluation of Global and Regional LV Function by MRI

\begin{tabular}{|c|c|c|}
\hline & Cell therapy & Primary PCI \\
\hline \multicolumn{3}{|l|}{$\operatorname{LVEF}(\%)$} \\
\hline Basal & $37.9 \pm 8.9$ & $41.8 \pm 7.0$ \\
\hline 6 month & $45.2 \pm 11.0$ & $47.8 \pm 9.8$ \\
\hline Change & $7.3 \pm 7.8$ & $6.0 \pm 9.0$ \\
\hline$p$ value & $0.033^{*}$ & $0.019 *$ \\
\hline \multicolumn{3}{|c|}{ LVEDV index $\left(\mathrm{ml} / \mathrm{m}^{2}\right)$} \\
\hline Basal & $89.5 \pm 28.4$ & $83.2 \pm 22.4$ \\
\hline 6 month & $91.2 \pm 32$ & $75.2 \pm 19.1$ \\
\hline Change & $1.8 \pm 22.9$ & $-7.9 \pm 19.2$ \\
\hline$p$ value & 0.889 & 0.121 \\
\hline \multicolumn{3}{|c|}{ LVESV index $\left(\mathrm{ml} / \mathrm{m}^{2}\right)$} \\
\hline Basal & $57.5 \pm 25.6$ & $50.1 \pm 17.2$ \\
\hline 6 month & $52.9 \pm 29.0$ & $44.4 \pm 16.8$ \\
\hline Change & $-4.5 \pm 21.2$ & $-5.7 \pm 9.4$ \\
\hline$p$ value & 0.441 & $0.044 *$ \\
\hline \multicolumn{3}{|c|}{ LVM index $\left(\mathrm{g} / \mathrm{m}^{2}\right)$} \\
\hline Basal & $58.8 \pm 8.8$ & $60.3 \pm 15.0$ \\
\hline 6 month & $58.7 \pm 13.9$ & $54.8 \pm 14.2$ \\
\hline Change & $-0.2 \pm 12.1$ & $-5.2 \pm 11.7$ \\
\hline$p$ value & 0.515 & 0.109 \\
\hline \multicolumn{3}{|c|}{ SWM, all $(\mathrm{mm})$} \\
\hline Basal & $5.0 \pm 1.9$ & $6.1 \pm 1.4$ \\
\hline 6 month & $6.2 \pm 1.9$ & $6.7 \pm 1.6$ \\
\hline Change & $1.4 \pm 1.4$ & $0.6 \pm 1.4$ \\
\hline p value & 0.066 & 0.121 \\
\hline \multicolumn{3}{|c|}{ SWM, infarct area $(\mathrm{mm})$} \\
\hline Basal & $3.8 \pm 1.6$ & $4.5 \pm 1.0$ \\
\hline 6 month & $5.3 \pm 1.7$ & $5.9 \pm 1.5$ \\
\hline Change & $1.5 \pm 1.4$ & $1.5 \pm 1.4$ \\
\hline$p$ value & $0.015^{*}$ & $0.002 *$ \\
\hline \multicolumn{3}{|c|}{ SWM, non-infarct area $(\mathrm{mm})$} \\
\hline Basal & $6.0 \pm 2.0$ & $7.2 \pm 2.3$ \\
\hline 6 month & $7.1 \pm 2.3$ & $7.8 \pm 2.0$ \\
\hline Change & $1.1 \pm 1.9$ & $0.6 \pm 1.7$ \\
\hline$p$ value & 0.110 & 0.179 \\
\hline \multicolumn{3}{|c|}{ Late contrast hyperenhancement $(\mathrm{g})$} \\
\hline Basal & $21.5 \pm 9.6$ & $22.8 \pm 11.4$ \\
\hline 6 month & $17.7 \pm 14.9$ & $15.1 \pm 7.8$ \\
\hline Change & $-3.8 \pm 11.7$ & $-7.7 \pm 12.2$ \\
\hline$p$ value & 0.345 & 0.071 \\
\hline
\end{tabular}

MRI, magnetic resonance imaging; LVEDV, left ventricular end-diastolic volume; LVESV, left ventricular end-systolic volume; LVM, left ventricular mass; SWM, systolic wall motion. Other abbrevistions see in Tables 1,2. Data are mean $\pm S D$ when appropriate.

${ }^{*} p<0.05$ between initial and 6-months follow up (Wilcoxon Signed Ranks test).

score index also improved significantly in all groups. The degree of improvement of the LV ejection fraction and the wall motion score index was not significantly different among groups (Table 2, Fig 2).

Paired MRI analysis revealed that the global LV function also improved significantly in both the cell therapy and primary PCI group. The relative improvement in the LV ejec- tion fraction was $7.3 \pm 7.8 \%$ for the cell therapy group and $6.0 \pm 9.0 \%$ for the primary PCI group. Analysis of the regional $\mathrm{LV}$ systolic wall motion revealed that the improvement of LV function was primarily derived from the improvement of the wall motion of the infarcted myocardium. The volume of late hyperenhancement, which is closely related to the irreversibly damaged myocardium, had a tendency to decline after 6 months but this was statistically not significant in both groups (Table 3, Fig 3)?

The coronary flow reserve of the cell therapy group improved from the baseline value of $1.82 \pm 0.49$ to $2.84 \pm 0.79$ at 6 months $(\mathrm{p}=0.006)$, which was similar to previous reports.,21,24

\section{Clinical Course}

With respect to clinical outcomes at 6 months, there were no deaths, MIs or hospital admissions in the cell therapy or primary PCI groups. In the delayed PCI group, there were 2 cardiac deaths. Also 4 patients of the delayed PCI group required hospital admission for the treatment of heart failure. Angiographic follow-up was performed in all cases of the cell therapy group at 6 months We identified 1 angiographic in-stent restenosis (diameter stenosis=50\%) at the site of sirolimus-coated stent implantation, but PCI was not performed because the patient was asymptomatic. In the primary PCI or delayed PCI groups, the 6-month angiographic follow-up was performed in 24 patients $(67 \%)$ and 16 patients $(52 \%)$, respectively. In-stent restenosis was identified in 2 patients of primary PCI group and 5 patients of the delayed PCI group, and PCI was repeated in 1 and 3 patients, respectively. In these groups, all restenosis was occurred at the site of the bare metal stent implantation.

We followed the patients for $787 \pm 99$ days. There were no additional deaths, MIs, revascularizations or hospital admissions in the cell therapy group. In the primary PCI group, 1 patient suffered sudden cardiac death and 2 patients have undergone elective PCI for progressed noninfarct-related lesions. In the delayed PCI group, there were 2 additional cardiac deaths and 1 additional rehospitalization due to heart failure. A survival analysis revealed that the combined risk of death, MI, revascularization and rehospitalization due to heart failure was the only significant trend across groups both at 6 months (cell therapy group: $0 \%$; primary PCI group: $3.2 \pm 3.1 \%$; delayed PCI group: $23.3 \pm 7.7 \% ; \mathrm{p}=0.027, \log$-rank test for trend) and at 2 years $(0 \% ; 6.8 \pm 4.7 \% ; 35.8 \pm 9.4 \% ; \mathrm{p}=0.022)($ Table 4$)$.

\section{Discussion}

The findings of the present study indicate that intracoronary transplantation of G-CSF mobilized PBSC may be safe, which is consistent with previous studies, but it may
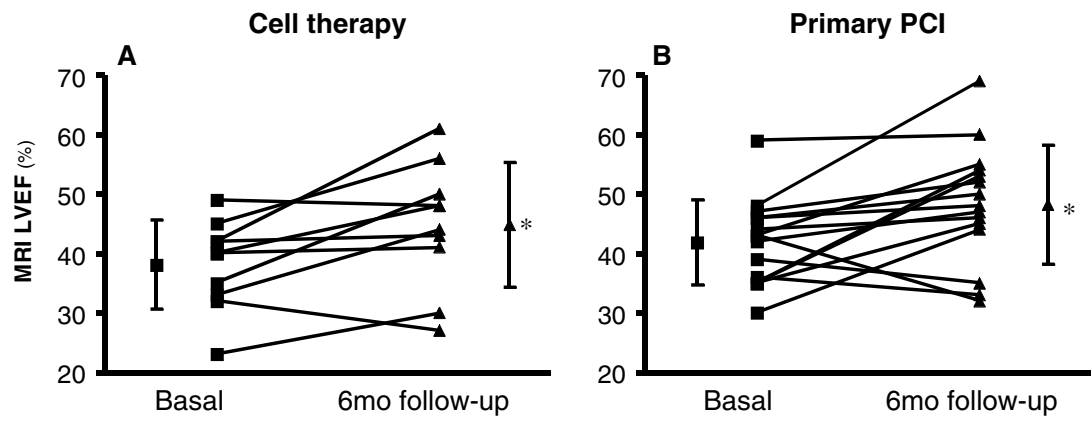

Fig 3. Improvement of left ventricular (LV) function evaluated by magnetic resonance imaging (MRI). LV ejection fraction (LVEF), measured initially and at 6-months follow-up, increased significantly in both the cell therapy and primary percutaneous coronary intervention (PCI) groups (A, B). Descriptive data are shown in Table $3 . * \mathrm{p}<0.05$ between initial and 6-months follow-up (Wilcoxon Signed Ranks test). 
Table 4 Clinical Follow up Results

\begin{tabular}{lccc}
\hline \hline & $\begin{array}{c}\text { Cell therapy } \\
(n=10)\end{array}$ & $\begin{array}{c}\text { Primary PCI } \\
(n=32)\end{array}$ & $\begin{array}{c}\text { Delayed PCI } \\
(n=31)\end{array}$ \\
\hline 6 months follow up & & & $0(0)$ \\
Non-fatal MI, $n(\%)$ & $0(0)$ & $0(0)$ & $3(10)$ \\
Target lesion revascularization, $n(\%)$ & $0(0)$ & $1(3)$ & $2(6)$ \\
Death, $n(\%)$ & $0(0)$ & $0(0)$ & $4(13)$ \\
Hospitalization due to heart failure, $n(\%)$ & $0(0)$ & $0(0)$ & $3(10)$ \\
MACE, $n(\%)$ & $0(0)$ & $1(3)$ & $7(23)$ \\
MACE + admission due to heart failure, $n(\%)$ & $0(0)$ & $1(3)$ & $0(0)$ \\
years follow up & $0(0)$ & $0(0)$ & $3(10)$ \\
Non-fatal MI, $n(\%)$ & $0(0)$ & $1(3)$ & $4(13)$ \\
Target lesion revascularization, $n(\%)$ & $0(0)$ & $1(3)$ & $5(16)$ \\
Death, $n(\%)$ & $0(0)$ & $0(0)$ & $7(23)$ \\
Hospitalization due to heart failure, $n(\%)$ & $0(0)$ & $2(6)$ & $12(39)$ \\
MACE, $n(\%)$ & $0(0)$ & $2(6)$ & \\
MACE + admission due to heart failure, $n(\%)$ & & & \\
\hline
\end{tabular}

MI, myocardial infarction; MACE, major adverse cardiac event, which is defined by death, MI, or target lesion revascularization. Other abbrevistion see in Table 1.

The combined risk of death, MI, revascularization, and rehospitalization due to heart failure is the only significant trend across groups both at 6 months and at 2 years $(p=0.022)$.

${ }^{*} p<0.05$ (log-rank test for trend).

not enhance the recovery of global LV function beyond that obtained by standard reperfusion therapy?,25 Cell therapy did not contribute to an additional increase in LV ejection fraction when evaluated using echocardiography and MRI. Also the changes in LV volumes over 6 months were not different significantly between cell therapy group and the other groups, which suggests a minimal effect on the $\mathrm{LV}$ remodeling?.25

\section{Benefit of Post-PCI Cell Therapy in AMI Patients}

The present study raises the issue of whether the bone marrow cells can enhance the improvement of LV function after AMI. The potential benefits of stem-cell transplantation were first shown in experimental animal MI models with large anterior infarctions.,3 However, the profound beneficial effect has not been reproducibly observed in clinical studies. The range of the improvement of LV ejection fraction varied from 0 to $8.6 \% \%^{4-10,25,26}$ In addition, there are still controversies about the myocardial regenerative capacity of adult stem cells. ${ }^{27-31}$

It has been well known that early reperfusion after AMI reduces the infarct size and preserves LV function. Recent studies using meticulous echocardiography or MRI analysis showed a 3 to 7 percentage point improvement in ejection fraction and a reduction of infarct size after primary PCI 20,21,32-34 In addition, recent randomized controlled clinical trials showed that LV function can also improve significantly after a late re-opening of the infarct-related artery 32,35

In the present study, we excluded patients with a high risk of developing congestive heart failure who might have enjoyed maximal benefits of stem cell therapy. In contrast, if ventricular function is too well preserved, functional improvement from stem cell therapy may be hardly expected. We were also concerned about the location of infarct and the site of vessel occlusion, which is known to affect the improvement of LV function and has been strictly controlled in successful animal models $!^{13-18}$ To overcome the potential bias described above, we enrolled only patients with proximal to mid LAD infarction. All our patients had a similar vessel occlusion site and large infarction size, which is most alike to the experimental models in which the profound effects of cell therapy were shown.

Although the clinical endpoint defined by the improvement of LV systolic function and the time to revascularization was similar between the cell therapy and delayed PCI groups, the cell therapy group has a shown comparable improvement of LV function despite of a higher maximal CK-MB compared to delayed PCI group $(174 \pm 266$ versus $45 \pm 60 \mathrm{U} / \mathrm{L}$ ). Furthermore, although it was not included as clinical endpoint at the stage of study design, there was a significant trend toward better clinical consequences in cell therapy group. A survival analysis showed that the combined risk of death, MI, revascularization and rehospitalization due to heart failure was better in cell therapy group $(0 \%)$ compared to primary PCI group (3.2\%) and delayed PCI group $(23.3 \%)$ after 1 year. So the potential benefits of cell therapy on myocardial function should be considered. First, the replacement of lost myocardial cells through the myocardial differentiation of infused cells, which was initially proposed, could be taken into account. However, subsequent studies failed to support these initial observations $3^{30,36}$ And it might have been confused with cellular fusion:37,38 So the likelihood of the differentiation of stem cells into functional cardiomyocytes would hardly exist. Second, the augmentation of resident cardiac stem cell proliferation by infused stem cells could be considered. Direct myocardial regeneration was identified in animals, ${ }^{39-42}$ and animal cardiac stem cells were suggested $43-45$ However, the existence of human cardiac stem cells has not been clearly proven yet 46 Third, the locally transplanted cells could act in a paracrine fashion to improve myocardial function through the release of growth factors or other paracrine mediators. Human adult stem cells mobilized by G-CSF are rich in bioactive cytokines, including many growth factors. These mediators may prevent apoptosis of ischemic myocardial cells or limit injury by promoting angiogenesis rather than tissue regeneration ${ }^{47,48}$ Pre-clinical studies have shown improvement in angiogenesis or the salvage of ischemic tissue by direct implantation of human adult stem cells on the ischemic skeletal or heart muscle?23,49-51 Fourth, the effect of cytokine used for the cell mobilization should be considered. G-CSF has been known to inhibit the apoptotic death of cardiomyocytes, increase arteriogenesis 
and augment intercellular connection. Therefore, G-CSF has been reported to lead to the promotion of the salvage of the injured myocardium, prevention of ventricular remodeling and reduction of inducible arrhythmia52-54 These hypotheses could be applied to the results of the present study, which were a comparative improvement of LV function in cell therapy group compared to the delayed PCI group despite a higher maximal CK-MB in the cell therapy group.

The cell processing method or cell dose might be an important issue in cell therapy. We used continuous G-CSF injection and peripheral blood stem cell apheresis followed by immediate intracoronary cell infusion, which has been tried in previous studies very successfully $4-6,8,9,24$ The dose of cells used in the present study was $2.03 \pm 0.69 \times 10^{9}$ of total mononuclear cells and $3.12 \pm 2.19 \times 10^{6}$ of CD $34+$ cells, which was comparable to or higher than previous trials and was only less than the BOOST trial $\left(2.46 \pm 0.94 \times 10^{9}\right.$ total mononuclear cell, 9.5 $\pm 2.19 \times 10^{6} \mathrm{CD} 34+$ cell), which showed no impact on intracoronary cell infusion on midterm LV function? In a MI involving $30 \%$ of the left ventricle, the number of cardiomycytes is known to be reduced by more than $1 \times 10^{9}$. Only 1 to $2 \%$ of mononuclear cells in bone marrow are CD34+ progenitor cells, and true functional stem cells are even scarcer ${ }^{5}$ Furthermore, it has been shown that most of infused human mononuclear cells were simply washed out and only $1.5 \%$ of infused cells could accumulate in myocardial tissue $, 56,57$ and a large proportion die after a few days $5^{58}$ Moreover, the most optimistic calculations from animal data indicate that the maximum amount of new myocardium generated during cell therapy would be 1 to $5 \mathrm{~g}$, from which the functional contribution to the human adult heart could be hardly measured 59,60 The results of the present study suggest that the efficacy of postPCI cell therapy is hardly conclusive, even in AMI patients most similar to the experimental AMI models with successful results.

In the present study, one patient in cell therapy group has shown to lack an improvement of LV function even with revascularization followed by stem cell therapy. It has been known that AMI patients treated with primary PCI had 3 to 7 percentage point improvement in ejection fraction when compared to the control groups $20,21,32-34$ However, in 25\% of treated patients, LV function deteriorates even with successful primary PCI ${ }^{6}{ }^{1}$ Our case described above may be a good example showing the limitations of cell therapy in the case of impaired improvement of LV function after primary PCI.

\section{Safety Issues}

There have been some concerns about the safety of GCSF or granulocyte-macrophagecolony-stimulating factor (GM-CSF) treatment for stimulating PBSC, because they may act as double-edged swords ${ }^{62}$ Both G-CSF and GMCSF have potent proinflammatory and procoagulant effects, and a number of cases of AMI and stroke have been reported!2,63 Recently 2 trials reported an apparent increase in acute coronary syndrome after the use of GCSF or GM-CSF 64,65 One trial, which used G-CSF before PCI, reported a marked increase of in-stent restenosis ${ }^{24}$

In the present study, G-CSF treatment was started at 6 days after PCI. The dose was $8.6 \pm 1.3 \mu \mathrm{g} \cdot \mathrm{kg}^{-1} \cdot$ day $^{-1}$ for 4 days, which conforms to the current recommendation to not exceed $8.8 \mu \mathrm{g} \cdot \mathrm{kg}^{-1} \cdot$ day $^{-1} .12 \mathrm{We}$ did not identify any periprocedural adverse events after G-CSF followed by intracoronary cell infusion. Target vessel revascularization as a result of restenosis and late lumen loss in the G-CSF treated cell therapy group was also scarce for the 2 years of follow-up, which was shown in only 1 clinically insignificant in-stent restenosis. Our data suggest that if G-CSF were used within the recommended dose and with a sufficient time interval from PCI, G-CSF might not enhance the restenosis process or adverse cardiac events.24,64,65 However, further examination of the safety of G-CSF treatment in AMI patients should be investigated with more patients and longer follow-up periods.

There are several limitations in the present study. The study design, which was decided by investigators and institutional review board, was open-labeled, which is weak relative to a placebo-controlled blinded study. Also, the clinical characteristics of 3 study groups were not identical. The number of study participants was relatively small and underpowered for many endpoints.

In summary, the present study provided further confirmation of the feasibility and safety of additional intracoronary infusion of autologous peripheral blood stem cell in AMI patients after successful PCI. However, there was no additional treatment effect on the recovery of LV function compared with the substantial recovery found in placebo group, suggesting specific benefits beyond those offered by mechanical revascularization might be limited. Based on the present study, larger adequately-powered and wellcontrolled clinical trials would be required to confirm the impact of post-MI cell therapy on the recovery of LV function and mid-term survival.

\section{Acknowledgments}

We thank to the enthusiastic support by the staff of our catheterization laboratories, by Sunghee Choi, and the staff of Samsung Biomedical Research Institute, by Koung Li Kim and Jaeok Shin.

\section{References}

1. Krum H, Gilbert RE. Demographics and concomitant disorders in heart failure. Lancet 2003; 362: 147-158.

2. Orlic D, Kajstura J, Chimenti S, Limana F, Jakoniuk I, Quaini F, et al. Mobilized bone marrow cells repair the infarcted heart, improving function and survival. Proc Natl Acad Sci USA 2001; 98: $10344-$ 10349.

3. Yoon YS, Wecker A, Heyd L, Park JS, Tkebuchava T, Kusano K, et al. Clonally expanded novel multipotent stem cells from human bone marrow regenerate myocardium after myocardial infarction. J Clin Invest 2005 ; 115: 326-338.

4. Assmus B, Schachinger V, Teupe C, Britten M, Lehmann R, Dobert $\mathrm{N}$, et al. Transplantation of Progenitor Cells and Regeneration Enhancement in Acute Myocardial Infarction (TOPCARE-AMI). Circulation 2002; 106: 3009-3017.

5. Schachinger V, Assmus B, Britten MB, Honold J, Lehmann R, Teupe C, et al. Transplantation of progenitor cells and regeneration enhancement in acute myocardial infarction: Final one-year results of the TOPCARE-AMI Trial. J Am Coll Cardiol 2004; 44: 16901699.

6. Wollert KC, Meyer GP, Lotz J, Ringes-Lichtenberg S, Lippolt P, Breidenbach $\mathrm{C}$, et al. Intracoronary autologous bone-marrow cell transfer after myocardial infarction: The BOOST randomised controlled clinical trial. Lancet 2004; 364: 141-148.

7. Ince $\mathrm{H}$, Petzsch M, Kleine HD, Eckard H, Rehders T, Burska D, et al. Prevention of left ventricular remodeling with granulocyte colony-stimulating factor after acute myocardial infarction: Final 1year results of the Front-Integrated Revascularization and Stem Cell Liberation in Evolving Acute Myocardial Infarction by Granulocyte Colony-Stimulating Factor (FIRSTLINE-AMI) Trial. Circulation 2005; 112: I73-I80.

8. Janssens S, Dubois C, Bogaert J, Theunissen K, Deroose C, Desmet $\mathrm{W}$, et al. Autologous bone marrow-derived stem-cell transfer in patients with ST-segment elevation myocardial infarction: Doubleblind, randomised controlled trial. Lancet 2006; 367: 113-121.

9. Meyer GP, Wollert KC, Lotz J, Steffens J, Lippolt P, Fichtner S, et 
al. Intracoronary bone marrow cell transfer after myocardial infarction: Eighteen months' follow-up data from the randomized, controlled BOOST (BOne marrOw transfer to enhance ST-elevation infarct regeneration) trial. Circulation 2006; 113: 1287-1294.

10. Ripa RS, Jorgensen E, Wang Y, Thune JJ, Nilsson JC, Sondergaard L, et al. Stem Cell Mobilization Induced by Subcutaneous Granulocyte-Colony Stimulating Factor to Improve Cardiac Regeneration After Acute ST-Elevation Myocardial Infarction: Result of the Double-Blind, Randomized, Placebo-Controlled Stem Cells in Myocardial Infarction (STEMMI) Trial. Circulation 2006; 113(16): $1983-1992$.

11. Hamano K, Nishida M, Hirata K, Mikamo A, Li TS, Harada M, et al. Local implantation of autologous bone marrow cells for therapeutic angiogenesis in patients with ischemic heart disease: Clinical trial and preliminary results. Jpn Circ J 2001; 65: 845-847.

12. Cavallaro AM, Lilleby K, Majolino I, Storb R, Appelbaum FR, Rowley SD, et al. Three to six year follow-up of normal donors who received recombinant human granulocyte colony-stimulating factor. Bone Marrow Transplant 2000; 25: 85-89.

13. Haim M, Hod H, Reisin L, Kornowski R, Reicher-Reiss $H$, Goldbourt U, et al. Comparison of short- and long-term prognosis in patients with anterior wall versus inferior or lateral wall non-Q-wave acute myocardial infarction: Secondary Prevention Reinfarction Israeli Nifedipine Trial (SPRINT) Study Group. Am J Cardiol 1997; 79: $717-721$.

14. Stone GW, Grines CL, Browne KF, Marco J, Rothbaum D, O'Keefe $\mathrm{J}$, et al. Influence of acute myocardial infarction location on in-hospital and late outcome after primary percutaneous transluminal coronary angioplasty versus tissue plasminogen activator therapy. Am J Cardiol 1996; 78: 19-25.

15. Behar S, Rabinowitz B, Zion M, Reicher-Reiss H, Kaplinsky E, Abinader $\mathrm{E}$, et al. Immediate and long-term prognostic significance of a first anterior versus first inferior wall Q-wave acute myocardial infarction: Secondary Prevention Reinfarction Israeli Nifedipine Trial (SPRINT) Study Group. Am J Cardiol 1993; 72: 1366-1370.

16. Brodie BR, Hansen C, Stuckey TD, Richter S, Versteeg DS, Gupta $\mathrm{N}$, et al. Door-to-balloon time with primary percutaneous coronary intervention for acute myocardial infarction impacts late cardiac mortality in high-risk patients and patients presenting early after the onset of symptoms. J Am Coll Cardiol 2006; 47: 289-295.

17. McClements BM, Weyman AE, Newell JB, Picard MH Echocardiographic determinants of left ventricular ejection fraction after acute myocardial infarction. Am Heart J 2000; 140: 284-289.

18. Sciagra R, Imperiale A, Antoniucci D, Migliorini A, Parodi G, Comis G, et al. Relationship of infarct size and severity versus left ventricular ejection fraction and volumes obtained from $99 \mathrm{mTc}$ sestamibi gated single-photon emission computed tomography in patients treated with primary percutaneous coronary intervention. Eur J Nucl Med Mol Imaging 2004; 31: 969-974.

19. Wang Y, Tang H, Wang D, Li R, Dong Y, Liu W, et al. Pretreatment with transmyocardial revascularization might improve ischemic myocardial function performed with cell transplantation. Circ $J$ 2006; 70: 625-630.

20. Baks T, van Geuns RJ, Biagini E, Wielopolski P, Mollet NR, Cademartiri $F$, et al. Recovery of left ventricular function after primary angioplasty for acute myocardial infarction. Eur Heart $J$ 2005; 26: 1070-1077.

21. Baks T, van Geuns RJ, Biagini E, Wielopolski P, Mollet NR, Cademartiri F, et al. Effects of primary angioplasty for acute myocardial infarction on early and late infarct size and left ventricular wall characteristics. J Am Coll Cardiol 2006; 47: 40-44.

22. Petersen SE, Voigtlander T, Kreitner KF, Horstick G, Ziegler S, Wittlinger T, et al. Late improvement of regional wall motion after the subacute phase of myocardial infarction treated by acute PTCA in a 6-month follow-up. J Cardiovasc Magn Reson 2003; 5: 487495.

23. Choi JH, Hur J, Yoon CH, Kim JH, Lee CS, Youn SW, et al. Augmentation of therapeutic angiogenesis using genetically modified human endothelial progenitor cells with altered glycogen synthase kinase-3beta activity. J Biol Chem 2004; 279: 49430-49438.

24. Kang HJ, Kim HS, Zhang SY, Park KW, Cho HJ, Koo BK, et al. Effects of intracoronary infusion of peripheral blood stem-cells mobilised with granulocyte-colony stimulating factor on left ventricular systolic function and restenosis after coronary stenting in myocardial infarction: The MAGIC cell randomised clinical trial. Lancet 2004; 363: $751-756$.

25. Zohlnhofer D, Ott I, Mehilli J, Schomig K, Michalk F, Ibrahim T, et al. Stem cell mobilization by granulocyte colony-stimulating factor in patients with acute myocardial infarction: A randomized controlled trial. JAMA 2006; 295: 1003-1010.
26. Valgimigli M, Rigolin GM, Cittanti C, Malagutti P, Curello S, Percoco G, et al. Use of granulocyte-colony stimulating factor during acute myocardial infarction to enhance bone marrow stem cell mobilization in humans: Clinical and angiographic safety profile. Eur Heart J 2005; 26: $1838-1845$.

27. Murry CE, Soonpaa MH, Reinecke H, Nakajima H, Nakajima HO, Rubart M, et al. Haematopoietic stem cells do not transdifferentiate into cardiac myocytes in myocardial infarcts. Nature 2004; 428: 664-668.

28. Murry CE, Reinecke H, Pabon LM. Regeneration gaps: Observations on stem cells and cardiac repair. J Am Coll Cardiol 2006; 47: 17771785.

29. Anversa P, Leri A, Kajstura J. Cardiac regeneration. J Am Coll Cardiol 2006; 47: 1769-1776.

30. Chien KR. Lost and found: Cardiac stem cell therapy revisited. $J$ Clin Invest 2006; 116: $1838-1840$.

31. Schachinger V, Tonn T, Dimmeler S, Zeiher AM. Bone-marrowderived progenitor cell therapy in need of proof of concept: Design of the REPAIR-AMI trial. Nat Clin Pract Cardiovasc Med 2006; 3 (Suppl 1): S23-S28

32. Steg PG, Thuaire C, Himbert D, Carrie D, Champagne S, Coisne D, et al. DECOPI (DEsobstruction COronaire en Post-Infarctus): A randomized multi-centre trial of occluded artery angioplasty after acute myocardial infarction. Eur Heart J 2004; 25: 2187-2194.

33. Piscione F, Galasso G, De Luca G, Marrazzo G, Sarno G, Viola O, et al. Late reopening of an occluded infarct related artery improves left ventricular function and long term clinical outcome. Heart 2005; 91: 646-651.

34. Silva JC, Rochitte CE, Junior JS, Tsutsui J, Andrade J, Martinez EE, et al. Late coronary artery recanalization effects on left ventricular remodelling and contractility by magnetic resonance imaging. Eur Heart J 2005; 26: 36-43.

35. Horie H, Takahashi M, Minai K, Izumi M, Takaoka A, Nozawa M, et al. Long-term beneficial effect of late reperfusion for acute anterior myocardial infarction with percutaneous transluminal coronary angioplasty. Circulation 1998; 98: 2377-2382.

36. Gaudette GR, Cohen IS. Cardiac regeneration: Materials can improve the passive properties of myocardium, but cell therapy must do more. Circulation 2006; 114: 2575-2577.

37. Matsuura K, Wada H, Nagai T, Iijima Y, Minamino T, Sano M, et al. Cardiomyocytes fuse with surrounding noncardiomyocytes and reenter the cell cycle. J Cell Biol 2004; 167: 351-363.

38. Terada N, Hamazaki T, Oka M, Hoki M, Mastalerz DM, Nakano Y, et al. Bone marrow cells adopt the phenotype of other cells by spontaneous cell fusion. Nature 2002; 416: 542-545.

39. Leferovich JM, Bedelbaeva K, Samulewicz S, Zhang XM, Zwas D, Lankford EB, et al. Heart regeneration in adult MRL mice. Proc Natl Acad Sci USA 2001; 98: 9830-9835.

40. Poss KD, Wilson LG, Keating MT. Heart regeneration in zebrafish. Science 2002; 298: 2188-2190.

41. Raya A, Koth CM, Buscher D, Kawakami Y, Itoh T, Raya RM, et al. Activation of Notch signaling pathway precedes heart regeneration in zebrafish. Proc Natl Acad Sci USA 2003; 100 (Suppl 1): 1188911895.

42. Lepilina A, Coon AN, Kikuchi K, Holdway JE, Roberts RW, Burns CG, et al. A dynamic epicardial injury response supports progenitor cell activity during zebrafish heart regeneration. Cell 2006; 127: 607-619.

43. Beltrami AP, Barlucchi L, Torella D, Baker M, Limana F, Chimenti $\mathrm{S}$, et al. Adult cardiac stem cells are multipotent and support myocardial regeneration. Cell 2003; 114: 763-776.

44. Linke A, Muller P, Nurzynska D, Casarsa C, Torella D, Nascimbene A, et al. Stem cells in the dog heart are self-renewing, clonogenic, and multipotent and regenerate infarcted myocardium, improving cardiac function. Proc Natl Acad Sci USA 2005; 102: 8966-8971.

45. Wu SM, Fujiwara Y, Cibulsky SM, Clapham DE, Lien CL, Schultheiss TM, et al. Developmental origin of a bipotential myocardial and smooth muscle cell precursor in the mammalian heart. Cell 2006; 127: 1137-1150.

46. Messina E, De Angelis L, Frati G, Morrone S, Chimenti S, Fiordaliso $\mathrm{F}$, et al. Isolation and expansion of adult cardiac stem cells from human and murine heart. Circ Res 2004; 95: 911-921.

47. Balsam LB, Wagers AJ, Christensen JL, Kofidis T, Weissman IL, Robbins RC. Haematopoietic stem cells adopt mature haematopoietic fates in ischaemic myocardium. Nature 2004; 428: 668-673.

48. Yoshioka T, Ageyama N, Shibata H, Yasu T, Misawa Y, Takeuchi $\mathrm{K}$, et al. Repair of infarcted myocardium mediated by transplanted bone marrow-derived CD34+ stem cells in a nonhuman primate model. Stem Cells 2005; 23: 355-364

49. Ishida A, Ohya Y, Sakuda H, Ohshiro K, Higashiuesato Y, Nakaema 
M, et al. Autologous peripheral blood mononuclear cell implantation for patients with peripheral arterial disease improves limb ischemia. Circ J 2005; 69: 1260-1265.

50. Xu X, Xu Z, Xu Y, Cui G. Selective down-regulation of extracellular matrix gene expression by bone marrow derived stem cell transplantation into infarcted myocardium. Circ J 2005; 69: 1275-1283.

51. Premaratne GU, Tambara K, Fujita M, Lin X, Kanemitsu N, Tomita $\mathrm{S}$, et al. Repeated implantation is a more effective cell delivery method in skeletal myoblast transplantation for rat myocardial infarction. Circ J 2006; 70: 1184-1189.

52. Harada M, Qin Y, Takano H, Minamino T, Zou Y, Toko H, et al. GCSF prevents cardiac remodeling after myocardial infarction by activating the Jak-Stat pathway in cardiomyocytes. Nat Med 2005; 11: $305-311$.

53. Kuhlmann MT, Kirchhof P, Klocke R, Hasib L, Stypmann J, Fabritz $\mathrm{L}$, et al. G-CSF/SCF reduces inducible arrhythmias in the infarcted heart potentially via increased connexin 43 expression and arteriogenesis. J Exp Med 2006; 203: 87-97.

54. Arai M, Misao Y, Nagai H, Kawasaki M, Nagashima K, Suzuki K, et al. Granulocyte colony-stimulating factor: A noninvasive regeneration therapy for treating atherosclerotic peripheral artery disease. Circ J 2006; 70: $1093-1098$.

55. Alison MR, Poulsom R, Forbes S, Wright NA. An introduction to stem cells. J Pathol 2002; 197: 419-423.

56. Kang WJ, Kang HJ, Kim HS, Chung JK, Lee MC, Lee DS. Tissue distribution of 18F-FDG-labeled peripheral hematopoietic stem cells after intracoronary administration in patients with myocardial infarction. J Nucl Med 2006; 47: $1295-1301$

57. Penicka M, Widimsky P, Kobylka P, Kozak T, Lang O. Images in cardiovascular medicine. Early tissue distribution of bone marrow mononuclear cells after transcoronary transplantation in a patient with acute myocardial infarction. Circulation 2005; 112: e63-e65.

58. Geng YJ. Molecular mechanisms for cardiovascular stem cell apoptosis and growth in the hearts with atherosclerotic coronary disease and ischemic heart failure. Ann NY Acad Sci 2003; 1010: 687-697.

59. Nadal-Ginard B, Fuster V. Myocardial cell therapy at the crossroads. Nat Clin Pract Cardiovasc Med 2007; 4: 1.

60. Fukuda K. Progress in myocardial regeneration and cell transplantation. Circ J 2005; 69: 1431-1446.

61. Ottervanger JP, Van't Hof AW, Reiffers S, Hoorntje JC, Suryapranata H, de Boer MJ, et al. Long-term recovery of left ventricular function after primary angioplasty for acute myocardial infarction. Eur Heart J 2001; 22: 785-790.

62. Wilson RF, Henry TD. Granulocyte colony-stimulating factor and granulocyte-macrophage colony-stimulating factor: Double-edged swords. J Am Coll Cardiol 2005; 46: 1649-1650.

63. Anderlini P, Przepiorka D, Champlin R, Korbling M. Biologic and clinical effects of granulocyte colony-stimulating factor in normal individuals. Blood 1996; 88: 2819-2825.

64. Zbinden S, Zbinden R, Meier P, Windecker S, Seiler C. Safety and efficacy of subcutaneous-only granulocyte-macrophage colony-stimulating factor for collateral growth promotion in patients with coronary artery disease. J Am Coll Cardiol 2005; 46: 1636-1642.

65. Hill JM, Syed MA, Arai AE, Powell TM, Paul JD, Zalos G, et al. Outcomes and risks of granulocyte colony-stimulating factor in patients with coronary artery disease. J Am Coll Cardiol 2005; 46: $1643-1648$ 